https://doi.org/10.3126/pragya.v7i1.35248

\title{
Impact of Gender inclusion in local government: A study based on Laltipur and Jhapa District
}

\begin{abstract}
.
This article focuses on the impact of gender inclusion in local government. This topic is based on gender inclusion theory, policy and programme of Nepalese government. This research examines the situation of knowledge of equal participation of female in decision making process, on policy and practices of local Government, and next is to understand the historical and patriarchal control over participation in decision making and influence of policy. It introduces to the Gender-aware approaches concerned with the manner in which such relationships are socially constructed; men and women play different roles in society, their gender differences being shaped by ideological, historical, religious, ethnic, economic and cultural determinants. It focuses on power relations and roles that challenges the existing women's subordination in the society. This research used in cross sectional descriptive and analytical research and all information is gathered and assessed on the issues- what and how they utilize resources benefits from local where the local people participate in different ways; what and how women use women's sectors fund and resources; how the social and cultural division of labour affecting in the decision making process in local government council and general meeting. Almost $90 \%$ respondents of study areas of both districts (Lalitpur and Jhapa) are affiliated political parties before they elected in local government. Almost $50 \%$ people of both Jhapa and Lalitpur district have the knowledge of gender inclusion. The practice of implementation of the formulated policies - program is gradually increasing in local government but still takes time to implement completely, but it seems that there is lacking of an effective awareness campaign. Increasing local government authority over service provision is pursued in part to reduce the gap between citizens and government authorities, as local government is considered closer to constituents. Whether or not LGs are able to continue to provide and improve services and develop infrastructure will be critical to the success of the new governance structure.
\end{abstract}

Sijapati Dipendra Bikram (M. Phil) \& Prof. Subedi, Govinda, PhD

Key word: Gender inclusion, local government, policy, programme and development, Introduction

The focus on gender rather than women was originally developed by feminists concerned about the manner in which the problems of women were perceived in terms of their sex, i.e., their biological differences with men, rather than in terms of their gender, i.e. in terms of the social relationship between men and women, a relationship in which women have been 
systematically subordinated.' Gender-aware approaches are concerned with the manner in which such relationships are socially constructed; men and women play different roles in society, their gender differences being shaped by ideological, historical, religious, ethnic, economic and cultural determinants. The gender world first introduced in 1985, Nairobi world conference, on woman. The gender refers to the socially constituted relations between men and women. It focuses on power relations and roles and challenges the existing women's subordination in the society. In Nepal, without appropriate intervention, the patriarchal (male-dominated) structure of society reinforces the status quo and may work against equity between men and women (Kabeer, 1994 Equality here is defined as equal distribution of benefits among the all people., irrespective of the differences among members in terms of their requirement.

Equity, (literally means proportionately equal) on the other hand, is a fair distribution of benefits based on the justice, basically the requirements. The challenges of attempting to integrate equity concerns with an environment in which resources scarcity is accentuating demands and increase conflicts in society (Bourdieu 2001).

Nepal is signatory to almost all international conventions on human rights, women's rights, and children's rights as well as to agreements on international goals regarding education, health, and poverty eradication. Nepal has thus committed itself to making rapid progress towards gender equality. The Convention on the Elimination of all forms of Discrimination Against Women (CEDAW), signed by Nepal in 1991, commits Nepal to constitutional and legal equality in all fields, while the Beijing Platform for Action commits it to promoting women's empowerment and formal and informal equality in all fields-economic, social, and political (Beijing,1995). The International Conference on Population and Development (ICPD) and ICPD+10 commit Nepal to ensuring women's universal access to reproductive health as well as equal access to all other health services. Similarly, Education for All (EFA) and the Millennium Development Goals (MDGs) commit Nepal to achieving minimum educational, health, and poverty reduction targets and making sure that women and girls share benefits equally as these goals are achieved (ICPD,1994)

These commitments reinforce the government of Nepal's promises of nondiscrimination, gender equity and social justice, already mandated by the Constitution of Nepal, 1990. The National Plan of Action - 2003 approved by the Government for the effective implementation of CEDAW and other human rights related instruments, guarantees all rights as per the CEDAW covenants. These include equal rights to citizenship, property ownership and inheritance, education, employment, and freedom from all kinds of violence. Equal rights and responsibilities in marriage and family are also included. Government of Nepal is to ensure all these rights to women by legal reforms, developmental measures, and 
affirmative action. Gender mainstreaming, strengthening anti-violence laws and implementation mechanisms, and empowering women through adequate choices in education, skill development, employment, and rights to reproductive health are specifically mentioned. Nepal's commitment to gender equality was further reinforced by its signature to ICPD-POA goals.

Gender inclusion and female empowerment are now universally recognized as core development objective fundamental for the realization of human right, and key to effective sustainable development in local development side (USAID, 2010). Gender inclusive is a major socio economic issue in Nepal, where female population is approximately 51 per cent in accordance with CBS, 2011. It is in total 9.6 million out of which CBS (2011) shows 67.5 per cent illiterate and 43.4 per cent absolute poor.

The government should officially recognize this job and make provision at VDC/DDC municipality level to allocate funds (Nominal) for them such that women's from poor and marginalized group (ADB, 2010).There is still issue of gender inclusiveness in decision making body and process and governance activities because of male dominance. It is urgently needed to understand what gender inclusiveness in LGs is, how local government provides opportunity to poor, backward and marginal female and what is its implication. (Sijapati, D.B., 2011).

After peaceful settlement of armed conflict, the Maoists participated in the legislature. The participation of Maoists in the legislature increased the percentage of the representation of indigenous peoples, women, Madhesis and other various marginalized communities. But an increase in the political representation has not necessarily solved the problem of poverty, health, education and unemployment, as Bahuns, Chhetris and Thakuris are still holding the major political power and control state's economic resources. Indigenous peoples, women, Madhesis, Dalits and other marginalized groups have neither any share in the resources nor do they have access to opportunities (Acharya, 2003 b).

Thus, compared to indigenous peoples and Madhesis, only 30 (12\%) women have been elected in the CA through the FPTP electoral system. But women occupy almost half of the total proportional seats in the CA. The election result shows that of the total declared 601 seats in the CA, women occupy 197 (32.77\%) seats in the Constituent Assembly. This numbers were not satisfied numbers with the election process as they demanded for full proportional electoral system, they are satisfied with the result of the election, because such a great representation even on ideological basis never happened before in the political history of Nepal. To a great degree, the result of the CA election confirms the success of indigenous peoples and other marginalized communities' movement for inclusive political 
and administrative system in Nepal. These elected members are more accountable to their political parties than to their own communities. Nevertheless, it is the major shift in the political history of Nepal (Gurung, 2009).

Half of the total proportional candidates for CA come from women. Despite the government's political commitment and constitutional provision of 33 percent of women's representation in the state mechanism, these big three political parties have failed to nominate 33 percent of women as FPTP candidates. Thus, compared to indigenous peoples and Madhesis, only $30(12 \%)$ women have been elected in the CA through the FPTP electoral system. But women occupy almost half of the total proportional seats in the CA. The election result shows that of the total declared 601 seats in the CA, women occupy 197 $(32.77 \%)$ seats in the Constituent Assembly. They were not satisfied with the election process as they demanded for full proportional electoral system; they are satisfied with the result of the election, because such a great representation even on ideological basis never happened before in the political history of Nepal.

\section{Objective}

\section{The objectives of this research are as follow:}

- To find out the situation of knowledge of equal participation of female in decision making process on policy and practices of local government.

- To understand the historical and patriarchal control over participation in decision making and influence of policy

\section{Methodology}

This study is based on cross sectional descriptive and analytical types of research design. Among the three main types of research - (exploratory, descriptive and analytical), analytical study is mainly descriptive in nature. The situation is explored in terms of gender, equality, equity and inclusion in local government. However, since the research locations like hills and plains are not similar as mentioned in justification (viz different type of geographical setting, socio-economic setting of people, extent and nature of poverty and gender index). Some of the variables need to be compared between and across the research locations. 


\section{Types of Information}

This research will attempt to present qualitative gender desegregated data relating to the elected in local government. Information will be gathered and assessed on the issues- what and how do they resources benefits from local benefit, whether the local people participate in different ways; what and how women use women's sectors fund and resources, how the social and cultural division of labour affecting the decision making process in local government council and general meeting; how all-women LGs are different from maledominated and what implications of operational plan of male-dominated LGs have on women's access to and control over governance body; what effect present policy and plan has on women's development sectors; what have been the constraints and what have been the supporting factors for the LGs to mainstream women.

\section{Sources of Information}

A multi-method information collection approach will be used. Basically, information needed to answer the research queries will be collected from primary and secondary sources of information. The information will be collected through literature review and several qualitative and quantitative techniques. The research hypothesis will be tested on the ground of primary data gathered in the sample size. However, secondary sources will supplement the empirical findings by various means. All available secondary data including progress and evaluation reports of related research and studies, seminar reports and proceedings and journals, constitutional books, Local government act, election commission reports and CBS report will be reviewed and analysed. This means that information will be collected at multiple sources viz. libraries, government and non-government offices to ensure the reliability of the research. Throughout the period of fieldwork, detailed notes will be maintained on observations relevant to the study area. Triangulation of data will be a major concern of the researcher throughout the study. The detail of qualitative and quantitative techniques used for primary data collection will be as outlined below.

\section{Primary Data Collection}

The primary dada have been taken applying three major methods i.e 1. Direct interview method, focus group method and key informant interview method through pre-structured research tool.

\section{Questionnaire Method}

Direct interview is conducting with the respondents (local government elected members) applying the pre structured questionnaires through census survey method. 


\section{Study population and sample size}

There are total 451 elected local bodies for local government. Out of them 405 are interviewed for required information collection through purposive or non probability methods because of number responded are constained.

\section{Sample Selection Procedure}

This study is based on the gender inclusion in local government. In this study, census method was used. Researcher has selected two districts and 358 wards elected body without chief and deputy chief of the research area because of the limitation of time and resources. District selection procedure is purposive sampling method (non- probability sampling). The respondents are selected on the basis of census method of the elected local body of the study areas.

\section{Analysis and Interpretation}

Gathered data and information from various sources and methods are compiled and analysed in two ways. Qualitative information are analysed through comparative logical analysis. Quantitative data collected through pre-structured questionnaires are analysed using SPSS (Statistical package for social sciences) software. Coverage error and content error are cross checked after the data collection. The data entered into SPSS database and results are obtained by frequency distribution and cross tabulation of the variables.

\section{Hypothesis testing}

Statistical Package for the Social Science (SPSS) verson 20 was used for analysing the quantitative data in -order to accomplish the statistical tests and hypothesis set for the study.

Chi-Square Test was undertaken to assess the characteristics of gender inclusion in local government who are elected members as the respondents. Basically, both dependent and independent variables are in nominal scales. Ttherefore, these types variable required to be tested in Chi Square Test in 0.05 insignificance confidence level.

A chi-square $\left(\chi^{2}\right)$ statistic is a test that measures how expectations compare to actual observed data (or model results). The data used in calculating a chi-square statistic must be random, raw, mutually exclusive drawn from independent variables, and drawn from a large enough sample. For example, the results of tossing a coin 100 times meet these criteria.

Chi-square tests are often used in the hypothsis testing. 
The Formula for Chi-Square Is

$$
\chi_{c}^{2}=\sum \frac{\left(O_{i}-E_{i}\right)^{2}}{E_{i}}
$$

\section{Where:}

$c=$ Degrees of freedom

$O=$ Observed value(s)

$E$ Expected value(s)

\section{Results}

Table 1: Distribution of the respondents by affiliation in a political party before their election in local government by selected characteristics, controlling for sex of the respondents (q2)

\begin{tabular}{|c|c|c|c|c|c|c|c|c|c|c|c|c|c|c|c|c|c|c|}
\hline \multirow{3}{*}{$\begin{array}{l}\text { Characterist } \\
\text { ics }\end{array}$} & \multicolumn{6}{|c|}{ Males } & \multicolumn{6}{|c|}{ Females } & \multicolumn{6}{|c|}{ Both sex } \\
\hline & \multicolumn{2}{|c|}{ Yes } & \multicolumn{2}{|c|}{ No } & \multicolumn{2}{|c|}{ Total } & \multicolumn{2}{|c|}{ Yes } & \multicolumn{2}{|c|}{ No } & \multicolumn{2}{|c|}{ Total } & \multicolumn{2}{|l|}{ Yes } & \multicolumn{2}{|c|}{ No } & \multicolumn{2}{|c|}{ Total } \\
\hline & $\mathrm{N}$ & $\%$ & $\mathrm{~N}$ & $\%$ & $\mathrm{~N}$ & $\%$ & $\mathrm{~N}$ & $\%$ & $\mathrm{~N}$ & $\%$ & $\mathrm{~N}$ & $\%$ & $\mathrm{~N}$ & $\%$ & $\mathrm{~N}$ & $\%$ & $\mathrm{~N}$ & $\%$ \\
\hline $\begin{array}{l}\text { Study } \\
\text { district }\end{array}$ & & & & & & & & & & & & & & & & & & \\
\hline Lalitapur & 134 & 95 & 7 & 5 & 141 & 100 & 77 & 88.5 & 10 & 11.5 & 87 & 100 & 211 & $\begin{array}{l}92 . \\
5\end{array}$ & $\begin{array}{l}1 \\
7\end{array}$ & 7.5 & 228 & 100 \\
\hline Jhapa & 74 & 94.9 & 4 & 5.1 & 78 & 100. & 48 & 92.3 & 4 & 7.7 & 52 & 100 & 122 & $\begin{array}{l}93 . \\
8\end{array}$ & 8 & 6.2 & 130 & 100 \\
\hline G.Total & 208 & 95 & 11 & 5. & 219 & 100. & $\begin{array}{l}12 \\
5\end{array}$ & 89.9 & 14 & 10.1 & $\begin{array}{l}13 \\
9\end{array}$ & 100 & 333 & 93 & $\begin{array}{l}2 \\
5\end{array}$ & 7 & 358 & 100 \\
\hline $\begin{array}{l}\text { Types of } \\
\text { Local } \\
\text { Governme } \\
\text { nts }\end{array}$ & & & & & & & & & & & & & & & & & & \\
\hline $\begin{array}{l}\text { Metropolita } \\
n s\end{array}$ & 79 & 95.2 & 4 & 4.8 & 83 & 100 & 42 & 82.4 & 9 & 17.6 & 51 & 100 & 125 & $\begin{array}{l}89 . \\
9\end{array}$ & $\begin{array}{l}1 \\
4\end{array}$ & $\begin{array}{l}10 . \\
1\end{array}$ & $\begin{array}{l}13 \\
9\end{array}$ & 100 \\
\hline $\begin{array}{l}\text { Municipalit } \\
\text { y }\end{array}$ & $\begin{array}{l}10 \\
0\end{array}$ & 97.7 & 3 & 2.3 & 103 & 100 & 82 & 96.9 & 2 & 3.1 & 67 & 100 & 165 & $\begin{array}{l}97 . \\
6\end{array}$ & 5 & 2.4 & $\begin{array}{l}17 \\
0\end{array}$ & 100 \\
\hline $\begin{array}{l}\text { Rural } \\
\text { Municipalit } \\
\text { y }\end{array}$ & 29 & 88.9 & 4 & $\begin{array}{l}11 . \\
1\end{array}$ & 33 & 100 & 18 & 87.5 & 3 & 12.5 & 21 & 100 & 47 & $\begin{array}{l}88 . \\
4\end{array}$ & 7 & $\begin{array}{l}11 . \\
6\end{array}$ & 54 & 100 \\
\hline
\end{tabular}

Sources:- Field Survey- 2076

As table 5.1, 95 percent male and 88.5 females were affiliated in political parties before they elected in local government of Lalitpur district. Same way, 94.4 percent male and 92.3 percent females were affiliated in political parties before they elected in local government in Jhapa districts (table 5.1)

While analyzed as types of local governments, 95.2 percent male and 82.4 percent female of metropolitan city, 97.7 percent male and 96.9 percent female of municipality and 88.9 
percent male and 87.5 percent female of rural municipality were affiliated in political parties before they elected in local government (table 5.1)

\section{Association (Chi-Square Test) Test}

a. Association between location of district and situation of affiliation in political parties before they elected in local government

\section{Output table}

\begin{tabular}{|l|c|c|c|c|c|}
\hline Characteristics & Value & df & $\begin{array}{c}\text { Asymptotic } \\
\text { Significance } \\
\text { (2 sided) }\end{array}$ & $\begin{array}{c}\text { Exact sig. (2 } \\
\text { sided) }\end{array}$ & $\begin{array}{c}\text { Exact Sig. } \\
\text { (1 sided) }\end{array}$ \\
\hline Pearson Chi-Square & $\mathbf{. 1 1 8 a}$ & $\mathbf{1}$ & $\mathbf{. 7 3 1}$ & & \\
\hline Continuity Correction & .053 & 1 & .817 & & \\
\hline Likelihood Ratio & .118 & 1 & .731 & & .408 \\
\hline Fisher's Exact Test & & & & .737 & \\
\hline Linear-by-Linear Association & .118 & 1 & .731 & & \\
\hline N of valid Cases & 358 & & & & \\
\hline
\end{tabular}

Here. Chi-Square $x^{2}$ value $=.118, \mathrm{df}=1$, Significance $(2$ sided $) /$ 'P' value $=.731$ and Apha ' $\alpha$ ' value $=0.05$

\section{Interpretation and conclusion}

Chi-Square $x^{2}$ value .118 is not significance as $\mathrm{P}$ value .731 and which is greater than Alpha ' $\alpha$ ' value 0.05 . Therefore, we reject the 'H1'alternative hypothesis and accept the 'Ho' Null Hypothesis. That means, there is no association between location of district and affiliation of respondents in political parties before they elected in local government. This chapter analyzed and interpreted the practice of gender inclusion and inclusiveness in local government by various characteristics i.e. districts, election areas, caste/ethnic groups, level of education, broad age groups and sex.

Table.2: Situation of the calling meeting and general assembly in the metropolitan city, municipality, rural municipality and ward by different characteristics

\begin{tabular}{|l|l|l|l|l|l|l|}
\hline \multirow{2}{*}{ Characteristics } & \multicolumn{6}{|l|}{ Practice of Gender Inclusion in local Government } \\
\cline { 2 - 7 } & Yes & No & \multicolumn{3}{l|}{ Total } \\
\hline Districts & Number & Percent & Number & Percent & Number & Percent \\
\hline Lalitpur & 223 & 62.3 & 5 & 1.4 & 228 & 63.7 \\
\hline Jhapa & 130 & 36.3 & 0 & 0.0 & 130 & 36.3 \\
\hline Grand total & 353 & 98.6 & 5 & 1.4 & 358 & 100.0 \\
\hline Election Area & & & & & & \\
\hline Lalitpur Metropolitan & 134 & 37.4 & 0 & 0.0 & 134 & 37.4 \\
\hline
\end{tabular}




\begin{tabular}{|l|l|l|l|l|l|l|}
\hline city & & & & & & \\
\hline Municipality & 165 & 46.1 & 5 & 1.4 & 170 & 47.5 \\
\hline Rural Municipality & 54 & 15.1 & 0 & 0.0 & 54 & 5.1 \\
\hline Grand total & 353 & 98.6 & 5 & 1.4 & 358 & 100.0 \\
\hline Male & 216 & 60.3 & 3 & 0.8 & 219 & 61.2 \\
\hline Female & 137 & 38.3 & 2 & 0.6 & 139 & 38.8 \\
\hline Grand total & 353 & 98.6 & 5 & 1.4 & 358 & 100.0 \\
\hline
\end{tabular}

Sources: Field Survey, 2076.

In Comparision to the two districts, more than third fifth percent (62.3\%) respondents of Lalitpur district and 36.3 percent respondents of Jhapa district said that there is practice of calling meeting and general assembly in the metropolitan city, municipality, rural municipality and ward. While analyzing by election areas, 37.4 percent respondents of metropolitan city, 46.1 percent municipality and 15.1 percent rural municipality said that there are practice of calling meeting and general assembly in their respective local area. Comparing three local areas, the highest are in municipality and lowest are in rural municipalities have Practice of Gender Inclusion in local Government (Table 2).

By sex, 60.3 percent male and 38.3 percent female respondents said that there are practice of calling meeting and general assembly in the local government. Highest are highest than female (Table 6.1).

\section{Output table}

\begin{tabular}{|c|c|c|c|c|c|}
\hline & Value & $\mathrm{Df}$ & $\begin{array}{c}\text { Asymp. Sig. } \\
\text { (2-sided) }\end{array}$ & $\begin{array}{l}\text { Exact Sig. (2- } \\
\text { sided) }\end{array}$ & $\begin{array}{l}\text { Exact Sig. (1- } \\
\text { sided) }\end{array}$ \\
\hline Pearson Chi-Square & $71.994^{\mathrm{a}}$ & 1 & .000 & \multirow{7}{*}{.000 } & \multirow{7}{*}{.000 } \\
\hline Continuity Correction ${ }^{\mathrm{b}}$ & 70.044 & 1 & .000 & & \\
\hline Likelihood Ratio & 84.495 & 1 & .000 & & \\
\hline Fisher's Exact Test & & & & & \\
\hline Linear-by-Linear & 71.793 & 1 & . 000. & & \\
\hline Association & & & & & \\
\hline $\mathrm{N}$ of Valid Cases & 358 & & & & \\
\hline
\end{tabular}

Here. Chi-Square $x^{2}$ value $=71.994, \mathrm{df}=1$, Significance $(2$ sided $) /$ ' $\mathrm{P}$ ' value $=.000$ and Apha ' $\alpha$ ' value $=0.05$

\section{Interpretation and conclusion}

Chi-Square $x^{2}$ value 71.994 is significance as $\mathrm{P}$ value .000 and which is less than Alpha ' $\alpha$ ' value 0.05 . Therefore, we accept the 'H1'alternative hypothesis and reject the 'Ho' Null 
Hypothesis. That means, there is association between location of districts and practice of calling meeting and general assembly in local government.

Output table

\begin{tabular}{|c|c|c|c|}
\hline & Value & df & Asymp. Sig. (2-sided) \\
\hline $\begin{array}{l}\text { Pearson Chi-Square } \\
\text { Likelihood Ratio } \\
\text { Linear-by-Linear Association } \\
\mathrm{N} \text { of Valid Cases }\end{array}$ & $\begin{array}{r}143.227^{a} \\
149.062 \\
114.985 \\
358\end{array}$ & $\begin{array}{l}2 \\
2 \\
1\end{array}$ & $\begin{array}{r}.000 \\
.000 \\
.000\end{array}$ \\
\hline
\end{tabular}

Here. Chi-Square $x^{2}$ value $=143.227, \mathrm{df}=2$, Significance $(2$ sided $) /$ ' $\mathrm{P}$ ' value $=.000$ and Apha ' $\alpha$ ' value $=0.05$

\section{Interpretation and conclusion}

Chi-Square $x^{2}$ value 143.227 is significance as $\mathrm{P}$ value .000 and which is less than Alpha ' $\alpha$ ' value 0.05 . Therefore, we accept the ' $\mathrm{H} 1$ ' alternative hypothesis and reject the 'Ho' Null Hypothesis. That means, there is association between election areas and practice of calling meeting and general assembly in local government.

\section{Conclusion}

Almost 90 percent respondents of study areas of both districts (Lalitpur and Jhapa) are affiliated political parties before they elected in local government. Almost 50 percent people of both Jhapa and Lalitpur districts have knowledge of gender inclusion. The mass media is most effective source to dissemination of the information to the general public but it has still lacking to bring the more effective awareness program activities. However, majority of the people of both districts have knowledge of different laws, acts, and policy programs related to gender inclusion in local government. But minority caste/ethnic groups have excessive low knowledge comparing to other caste/ethnic groups. There is no difference between rural municipality and municipality and metropolitan city to obtain the knowledge. The people with Secondary level education have more knowledge on the issue comparing to people with primary level education and it is the usual and natural phenomenon.

The local government personnel have formulated the different gender inclusion policy program activities including women friendly budget and others required policy programs as guided by the Nepal Constitution 2072, national and local government policy after they have elected in the local government.

The practice of implementation of the formulated policies - program is gradually increasing in local government but still takes time to completely implementation but seems there is lacking of an effective awareness campaign. 
As focus groups discussion, key informant interview and direct interview with the local government personnels, the local government offices are doing practice of solving the problems of local people formulating the unit of problems solving (Sthaniya Sarkar Melmilap Kendra) but sometimes they tried to solve the anti-social activities (criminal cases for example rape cases and so on) in local areas without consciences and regards of action agents (police office and court). So criminal could benefit and victims could more victimize. Ultimately, majority of the population assesses the success of local government by their effectiveness in providing services. Increasing local government authority over service provision is pursued in part to reduce the gap between citizens and government authorities, as local government is considered closer to constituents. Whether or not LG are able to continue to provide and improve services and develop infrastructure will be critical to the success of the new governance structure. In particular, research may choose to assess some of the indicators based on local government service provision in selected sectors, such as health, education, water and sanitation, and roads.

\section{Recommendation}

1. To improve service delivery, partner with women in local government.

2. Advocate for policies that promote women's presence in local government.

3. Advocate for quotas of women's representation at all levels and within all positions of government.

4. Encourage innovative mechanisms, such as Rwanda's "triple balloting" system, to realize quotas at the local level, build willingness to vote for women, and create more broadly representative elected bodies.

5. Support women's groups and enhance their links with local government.

6. Provide opportunities for women's participation at the most local level of government, particularly by encouraging female civil society leaders to organize meetings with elected and appointed leaders.

\section{Acknowledgement}

I would like to thank University Grant Commission Nepal which provided me $\mathrm{PhD}$ scholarship PhD-74/75-H \& S-12 and I would like to thank to the Tribhuvan University Teacher Association Patan Multiple Campus Unit and Patan Pragya Peer Revier research journal Editorial Board which selected and published this article.

\section{References}

Acharya, Meena (2003): Towards Conflict Transformation in Nepal: Recent Trends in

ADB, (2010). Overview of Gender Equality and Social Inclusion in Nepal (2003 b). ADB, Published by All Right Reserved 2010.

CBS, (2011).Population Census report. National Planning Commission Secretariat, Ramshah Path, Kathmandu. 
DFID/WB(2005) "Citizens With (Out) Rights: Nepal Gender and Social ExclusionAssessment”, Summary Report, Kthmandu, Nepal.

Government of Nepal,. (1015). Constitution Bill of Nepal, Constitution Drafting Committee Constituent Assembly Secretariat, Singha Durbar. Kathmandu

Government of Nepal.( 2072). Gali and Beijoti Act 2016 (Ammendment 2072). Ministry of Home and Afire. Singhdurbar, Kathmandu.

Gurung, Om, (2009). Social Inclusion: Policies and Practices in Nepal.

HMG, (1999). Local Self-Governance ACT, 2055 B.S. HMG, Nepal.

HMG, (1999). Local Self-Governance Regulation, 2056 B.S., Published by Nepal Gazette, 30 Dec. 1999.

HMG/N, Ministry of Women, Children and Social Welfare, Mainstreaming Gender Equity Programme (MGEP), UNDP, Kathmandu, Nepal.

International Conference Population and Development, (1994).Eliminating Human Traffinking and Prostitution. Cairo (ICPD 1994) PP. 46.

Kabeer, N. (1994). Reversed Realities, Gender Hierarchies in Development Though, London: Verso

MOHP/HMG (2005), "NEPAL Report on ICPD at Ten”, Ministry of Health and

National Planning Commission (2007). The Tenth Plan. Kathmandu: NPC National Planning Commission, Nepal. 2008. Three-year Interim Plan 2007 -NEFAS/FES ， Kathmandu

Nepal Communist Party (Amale) (2074).Party Election Manifesto. Party Office, Dhumbari Kathmandu, Nepal.

Nepali Congress Party, (2017).Party Election Manifesto: Election of Upper House Parliament Members and Local Level. Party Office, Kathmandu, Nepal

Nepali Congress Party, (2017).Party Election Manifesto: Election of Upper House Parliament Members and Local Level. Party Office, Sanepa, Lalitpur, Nepal

Sanghiya Samajbadi Forum Nepal., (2017). Party Menifesto: election of Upper House and Local Level, Party Office, Balkumari, Kathmandu

Sijapati, D. B. (2013). The Status of Gender Inclusion in Community Forestry of Nepal: A Case Study of Lalitpur District. An Unpublished Thesis of M. Phil, CDPS, T.U.

UN, (1983). Establishment of the Committee on the Elimination of Discrimination against Women, CEDAW

UN, (1994). International Conference on Population and Development, Cairo; adoption of the Programme of Action

UN, (1995). Fourth World Conference on Women, Beijing; adoption of the Platform of Action.

UN, (2000). UN Millennium Summit (Millennuim Development Goals. 